Article

\title{
For the Love of Dogs: Finding Compassion in a Time of Famine in Pali Buddhist Stories
}

\author{
Phyllis Granoff
}

Department of Religious Studies, Yale University, New Haven, CT 06520, USA; phyllis.granoff@yale.edu

Received: 15 February 2019; Accepted: 8 March 2019; Published: 12 March 2019

\begin{abstract}
This paper focuses on stories from the 13th century Rasavāhin in which feeding a starving dog is described as an act of great merit, equal even to the care of a monk or the Buddha. It begins with a reevaluation of passages from Buddhist texts that have been taken by scholars as evidence of pan- Buddhist concern for taking care of animals. It argues that they have been over-read and that the Rasavāhinī stories are distinctive. The setting in which these acts occur, a catastrophic famine, helps us to understand the transformation of the despised dog into an object of compassion. In such dire circumstances, when humans themselves behave like animals, compassion for a starving dog is both a new recognition of a fundamental shared kinship between human and animal and a gesture of recovering lost humanity.
\end{abstract}

Keywords: dogs; Buddhism; famine; merit

\section{Introduction}

A wide range of Buddhist texts teach that being reborn as an animal is a retribution for grievous sin. Given that as a starting point, it follows naturally that life as an animal is a life of pain and suffering. ${ }^{1}$ Indeed, the pain and suffering in the animal realm are likened to the torments of hell. ${ }^{2}$ Those in hell may receive succor from the visits of monks, the light emanated from the Buddha, from Bodhisattvas like Kșitigarbha and Avalokoteśvara, or from the performance of rituals done by ordinary mortals and pious donations of relatives. But in this paper, I argue that there is little help offered to the former sinners in the animal realm, with a few exceptional stories that come not from any canonical text but from a late story collection compiled in Śrī Lañkā, the Rasavāhinī of the 13th-century monk Vedeha Thera. I suggest that the elevation of the act of feeding an animal to an act of great merit, equal to feeding a monk or caring for a sick monk, is related to the context in which these acts occur in the stories, a time of great famine. It is at such a time, when humans have become themselves like animals, eating scraps of leaves and whatever rotten food they can find, when they have even become like demons, devouring human flesh, that the gift of food to a starving animal becomes both an acknowledgement of a new shared kinship between human and animal and a way to reassert the possibilities of human morality. ${ }^{3}$

The starving animal in the stories of the Rasavāhinī is a dog. This is perhaps not surprising, for dogs are considered to be an indispensable part of the human landscape in the texts that I consider here.

1 Ohnuma (2017), Unfortunate Destiny has a convenient summary in her first chapter of the standard descriptions of the animal rebirth. These and other references are to be found in Schmithausen and Maithrimurthi (2009) 'Attitudes Towards Animals in Indian Buddhism', pp. 47-121.

2 Nāham bhikkhave añ̃am ekadhammampi samanupassāmi evamdārunam emam katukam evam antarāyakaram anuttarassa yogakkhemassa adigamāya yathayidam bhikkhave nirayabandhanam vā tiracchānayonibandhanam vā, ti. I I Inasutta, Anguttaranikāya.

3 I thank Reiko Ohnuma for encouraging me to move this analysis, which found its place at the end of the paper, to the beginning. I also want to thank Barbara Ambros for her helpful comments. 
Thus in the Valăhaka Jātaka (Jātaka 196), when demon ladies want to lure unsuspecting shipwrecked merchants to their abode so that they can eat them, to make the merchants believe that they have reached a human habitation the yakkhinīs create phantom people plowing and trading; and they create cows and dogs. ${ }^{4}$ In the Visuddhimagga, chapter 11, when the fifth century scholar Buddhaghosa describes the utter repulsiveness of what a monk must see and do when he seeks for, receives and consumes alms, dogs figure several times. While there are no dogs on the grounds of the monastery, once the monk reaches the city gate, he is confronted with the sight of their corpses along with the bodies of dead humans. In the village he must avoid stepping on dog and pig excrement. Dogs are everywhere once the monk leaves the monastery and comes to the village. If the reader had any doubt that their presence is a cause of disgust, this is removed by the stomach-churning description of the monk eating the alms that follows the graphic account of his walk from the monastery to the village. The monk chews the food, reducing it to something that looks like what a dog eats, we are told, and then further moistening the food with spit, he turns it into something approximating dog vomit. ${ }^{5}$ The text continues, instructing monks to look on eating not as something pleasurable but, in this way, as something necessary but nonetheless repulsive.

The close proximity of dogs to humans makes them an easy object of both affection and opprobrium. Across all of India's religions and in every genre of literature it is the latter that prevails. Dogs are most often the object of fear, disgust and scorn. ${ }^{6}$ The worst thing the Buddha can say to a Brahmin is that the qualities that once existed among Brahmins in ages past now exist in dogs. ${ }^{7}$ A person who is addicted to sensual pleasures is like a dog that is bound by a chain and must walk in circles, unable to break free. In the end such a person meets a fate as unhappy as that which awaits the dog. It falls into the hands of a hungry outcaste who kills it for food. ${ }^{8}$ For Buddhaghosa, in his commentary to the Cetanā sutta of the Anguttaranikāya, dogs figure among the creatures who torment the monks and nuns, chasing after them and biting them. In doing so, they create for themselves bad kamma, akusalakamma. ${ }^{9}$ Elsewhere, he uses them as a negative example of how a monk should not eat food; he should not eat like a dog, for dogs know no limit to their eating and eat way beyond what is necessary. ${ }^{10}$

A Sanskrit text on the retribution of deeds perhaps from the 4th century, the Mahākarmavibhanga, tells a story that was sufficiently popular to have been depicted several times in Gandharan sculpture. When the Buddha visits a householder his pampered dog barks at the Buddha. The Buddha rebukes the dog, saying, "Have you still not learned your lesson, that you still do that which led you from being a Brahmin to being reborn as a dog?" The Buddha eventually explains to the householder that the dog was his father in a previous birth but had harbored ill feeling towards the Buddha, resulting in his terrible rebirth as a dog. ${ }^{11}$

Even where dogs are deemed useful to human beings, as omens, for example in the Bṛhatsamnitā, indicating favorable or unfavorable consequences, or in the royal hunt, as in the late medieval hawking manual, the Śyainika Śasstra, there is nothing positive said about them. ${ }^{12}$ In contrast to the wide range

4 Tesam "manussāvāsam àgatamhā"ti sañjānanattham tattha tattha kasigorakkhādīni karonte manusse gogaṇe sunakheti evamādīni dassenti. Valāhakassajātakavaṇnanā, Jātaka 196.

5 Visuddhimagga, Samādhiniddeso, I, 11, pp. 294-305. Translation, Bhikkhu Nānamoli, pp. 338-41.

6 For a studies of some examples of dogs in Indic literature see White (1991), Myths, and Bollée (2006), Gone to the Dogs. A famous exception to the general rule that dogs are the object of scorn is King Yudhisthira's refusal to abandon the dog that has followed him on his final journey. The dog is, however, not a dog, but the god Dharma in disguise. For a discussion of this episode in the epic see Doniger (2009), Hindus: An Alternative History, chp. 10, "Yudhishthira's dog".

7 Sonasutta, Ainguttaranikāya, pañcakanipāta, Brāhmanavaggo. These include such things as having sex only with one's own kind or having sex only when the female is in her fertile period.

8 Therīgāthā 511 on the nun Sumedhā.

9 Cetanāsuttavannanāā, Añguttaranikāya.

10 Commentary to the Puttamāmsūpamasutta, Samyuttanikāya.

11 Mahākarmavibhanga, pp. 22-32. For an illustration see Zwalf (1996), p. 236.

12 Bṛhatsamhitā, chapter XXVIII, verses 9-10; Śyainika Śāstra Chapter 3, verses 64-67. A king in the Padmapurāna, Bhūmikhanḍa, chps. $42-45$, also hunts with a pack of dogs. 
of negative associations that dogs have in virtually all of Indian literature, here I explore stories in which the usual fear and disdain of dogs are replaced by something close to empathy for their plight. ${ }^{13}$ I begin my reexamining some of the evidence frequently cited as proof of Buddhist concern for animals and then proceed to a consideration of the Śri Lankan stories. In the concluding section of the paper, I focus on the particular setting in which dogs invite compassion and caring for them brings great merit in these stories. This is a massive famine, and I argue that a time of such terrible suffering may have led to a reassessment of what it means to be human and what it means to be the lowliest of animals.

\section{The Merits of Feeding Animals: Reexamining the Evidence}

The strategy that Buddhist texts employ to encourage an action, and they are not unique in this, is to state carefully the reward for doing it. The main text that scholars cite that associates a gift to an animal with merit is a short Pali text in the Majjhima nikāya, the Dakkhināvibhainga sutta. ${ }^{14}$ The comment on the merit of making a gift to an animal occurs at the end of a description of the fourteen kinds of recipients of gifts. The recipients are arranged in a strict hierarchy, with the gift to the Buddha as the most meritorious and having the greatest reward and a gift to those in the animal realm, tiracchannagata as the lowest and of the least reward. The gift to a denizen of the animal realm is said to have its reward in the hundreds, while a gift to an ordinary person who is of bad conduct, puthujanadussila, has its reward in the thousands. The gift to an arhat, a paccekabuddha and the tathāgata himself is incalculable. ${ }^{15}$

It is instructive to read Buddhaghosa's comments on this passage. Buddhaghosa says that this does not include keeping an animal as a pet and feeding it, either because you are taken with the animal's special qualities or because you derive some benefit from the animal. It is reserved for the case when an animal, a dog, a pig, a chicken or a crow, has by chance approached you. And it must be given in full and with the intention to gain merit. ${ }^{16}$

There are a number of interesting points in the way in which Buddhaghosa seeks to define the circumstances in which a gift to an animal brings about merit. The animals Buddhaghosa mentions are all animals that one would expect to encounter in an average village; one might feed at least some of these and derive some benefit from them. Such cases are excluded. The gift must be given only with the intention of deriving merit and for no other purpose, and it must be ample. Buddhaghosa's wording here is important. He says giving an ālopa or a half an ālopa does not bring merit. The word alopa can simply mean a small measure; it is also a technical term that refers to a small amount of food taken by a monk from whatever he has received as alms. ${ }^{17}$ I return to this below.

The commentary or $T \bar{i} k \bar{a}$ on this passage elaborates further. It specifies food and protection as the potential benefits one might get from an animal. Giving something to animals that you are raising for these purposes brings no merit; it does not even meet the definition of a "gift". A gift, the text continues, is the giving up of something that belongs to you that is done without any desire for something in return from the recipient and without any desire to be particularly honored by the recipient. A gift

13 For some comments on the treatment of dogs in Buddhist literature see (Masset 2009), 'Le chien', pp. $573-97$.

14 Dakkhināvibhanga sutta, Majjhimanikāya. Cited by Schmithausen, 58 and note 55 . The sutta is also cited in the Abhidharmakośabhāsya. 270, p. 5.

15 "Tatrānanda, tiracchānagate dānam datvā sataguṇā dakkhiṇā pāțikañkhitabbā, puthujjanadussīle dānam datvā sahassagunā dakkhin̄ā

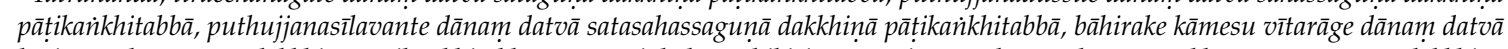

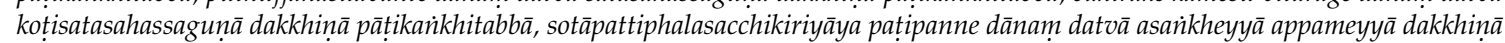

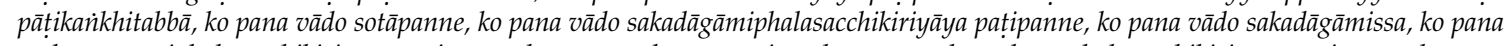
vā́do anāgāmiphalasacchikiriyāya patipanne, ko pana vādo anāgāmissa, ko pana vādo arahattaphalasacchikiriyāya pațipanne, ko pana vādo arahante, ko pana vādo paccekasambuddhe, ko pana vādo tathāgate arahante sammāsambuddhe!

16 Tattha tiracchānagateti yam gunavasena upakāravasena posanattham dinnam, idam na gahitam. Yampi ālopaaddhaālopamattam dinnaṃ, tampi na gahitam. Yạ̣ pana sunakhasūkarakukkuṭakākādīsu yassa kassaci sampattassa phalam pațikan்hițā yāvadatthạ̣ dinnaṃ, idam sandhāya vuttạ̣ "tiracchānagate dānam datvā"ti.

17 A monk is to eat four or five ālopas, or renounce eating even that and take only water. Theragāthatthakathā on verse 983 , cattāro pañca ālope abhutvā udakạ̣ pive. 
cannot be given out of fear, passion, or desire for gain. ${ }^{18}$ In addition, something that is not given in full and does not completely meet the needs of the recipient is also not meritorious. The Ti $\bar{k} \bar{a}$ does not gloss $\bar{a}$ lopa as a technical term, but takes it simply to mean a small measure of something. This is important as we move to the next group of texts that have often been cited as an indication that Buddhist texts positively encourage the feeding of animals.

In a Hindu law book that dates from around the 2nd century BCE, the Baudhāyana Dharmasūtra, an ascetic is supposed to offer a portion of the food he has received from begging to "all creatures" as an act of compassion. ${ }^{19}$ Buddhaghosa's use of the term ālopa if it is taken in its technical sense to mean a portion from a monk's alms bowl, might suggest that Buddhist monks regularly followed a similar practice. This is, however, not entirely clear. There are several things that mitigate against such an assumption. The first is that, as we have seen, the Ti $\bar{k} \bar{a}$ commentary on Buddhaghosa does not take the term in that way; it simply takes it to mean that the amount given was too little to meet the needs of the animal to which it was given.

In addition, passages from Mahāyāna texts that have been adduced to support the hypothesis that Buddhist monks set aside a portion of their alms for animals are not decisive. These are passages that deal with a bodhisattva's behavior towards others. Although the term often used for the recipient of a Bodhisattva's kindness, vinipatita, "a fallen creature", might be taken as analogous to the Pali usage of vinipāta, a term used for different bad rebirths, in many cases in Mahāyāna texts, it clearly refers to unfortunate humans and not animals. ${ }^{20}$ Thus in the Bodhisattvabhimi composed by the monk Asanga in the 4th century, a Bodhisattva is to treat even those who are younger than he is, even those who are less virtuous, with respect. He is to proclaim even the slightest virtue that the person has and to conceal his faults. He is not to laugh at him when he stumbles or take advantage of him when he falls (vinipatati). And he is to greet respectfully those who are his superiors, his equals and his inferiors. ${ }^{21}$ In a widely circulated Mahāyāna sūtra, the Gandavyūha, those who are vinipatita figure in a list of unfortunate people, the elderly, the sick, the poor, and those without food or clothing. ${ }^{22}$ It is thus not certain that when an 8th century compendium of Buddhist teachings, the Śikșasamuccaya, cites the Mahāyāna sūtra Ratnamegha, instructing that a monk must give some of his food to those in distress, duhkhitānām, and some to those who have come to ruin, vinipatitānām, that animals are the intended recipients. ${ }^{23}$ A passage from another Mahāyāna sūtra, the Ratnarāśi Sūtra, also cited in the Śikșāsamuccaya enjoins a monk who receives abundant alms to retain his practice of eating only a little. He is to place some of the food on a rock with these words," May the birds and beasts who are in need of food take this food which is given and eat it". ${ }^{24}$ The point of this injunction seems more to protect the rule that monks should eat little, be mitabhojin, in the language of the text, than to encourage a monk to feed animals. An injunction to feed animals, I would argue, would not be reserved for the case when a monk had received a lot of food. This passage makes an interesting contrast to a discussion in

18 Anuggahapūjanicchāvasena hi attano deyyavatthupariccāgo dānam bhayarāgaladdhukāmakulādivasena sāvajjäbhāvato

19 Cited by Schmithausen, 58 note 59. The line in question is this, Baudh2.10.18.10/bhütebhyo dayā.pūrvam (samviobhajya śeșam adbhiḥ(samsprśsyâauṣadhavat (prāśnīyāt "After distributing portions of his food to living creatures out of compassion, he should sprinkle water over the remainder and eat it as if it were medicine. Translation Olivelle, 208.

20 Sāmaññaphala sutta, Dīghanikāya, durgatim vinipätạn nirayaṃ upapannā, para. 246. Cited in Schmithausen, 79, note 170. Schmithausen notes that this term probably did not in any case refer to animals, but to some kind of miserable underworld. His reference to the use of the term to refer to animals in the Bālapandita Sutta in the Majjhimanikāya is more certain, Schmithausen, 85, although it probably refers to hell-beings as well as animals. Bālapandita sutta, Majjhimanikāya, 252.

21 Bodhisattvabhūmi, hīnam vā punarvayasā gunaiśca drsțā saktyā gunāähānamārabhya protsāhayati/bhūtañcāsya gunam svalpamapyudbhāvayati/bhūtañca doșaṃ praticchädayati/na viṿ̛noti yenāsya syānmaṃkubhāvah/na cainamavamanyate/nāpyarthikam kenaciddharmāmisena tam jñätvā vimukho bhavati bhrkutīkrtah/nāpi cainam skhalite'vahasati/nāpi vinipatitam paribhavati.

22 tadanyeșāmapi sattvānām ṿ̛ddhānāmāturānām daridrānām vin vinipatitānāmaśanavasanaviprahīnānām sạ̣vibhāgam kuryāti.

23 The passage in the Śikșāsamuccaya is cited by Schmithausen, 58, note 59. In another passage in the same text, this time cited from the Ratnarāśisūtra, vinipatita clearly refers to a human being. yasmād atroktam I pratyuddhāratām avabhāsatām ca pratilabdhukāmena | mahāndhakārād ālokam praveștukāmena | yad bhūyasā vinipatitena sādhyaị $\mid$.

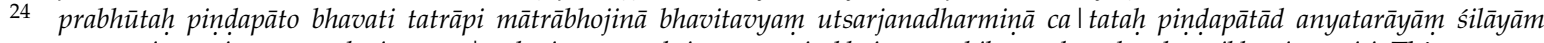

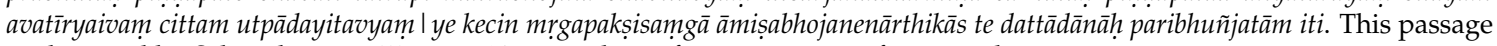
is also cited by Schmithausen, 59 , note 64 , as evidence for active caring for animals. 
the Manorathapūrañi, Buddhaghosa's commentary to the Pali collection of suttas in the Anguttaranikāya. There we learn that if a monk receives an abundance of tasty food he is to distribute it among the elders, the learned, those who received little and the sick. Nothing is said about giving to animals. After the monk has distributed what he has received, he can take from the others what they have been given or go back on his begging round. Such a monk is praised for being one who is satisfied with whatever he receives. ${ }^{25}$

Among prescriptive texts often cited as evidence of Buddhist compassion to animals, what remains then, is a brief passage in a Pali sutta, the Dakkhināvibhanga of the Majjhimanikāya that tells us that in some limited cases giving to a stray animal is meritorious. When we turn to story literature, the situation is not much different. Among the other texts that have been offered in support of the hypothesis that Buddhists actively encouraged feeding animals are several Jātakas. These, too, I would argue, offer at best limited support of pro-animal Buddhism. I consider first the Kukkura Jātaka, Jātaka 22. The plot of this Jātaka is simple. The Buddha has been born as a dog, and a rather unfortunate one at that. The Bodhisattva-dog lives in the cemetery. One day the king learns that dogs have eaten the leather trappings of his carriage. The king does not for a moment doubt his own fancy dogs and orders the slaughter of all the other dogs in the city, wherever they are to be found. The dogs that are threatened with death gather around the Bodhisattva and tell him about the terrible danger that they are in. The Bodhisattva at once realizes that it must be the palace dogs who have done this; there was no way for a dog outside the palace even to have gotten in there to do anything wrong. The Bodhisattva reassures the dogs, who are his relatives, and betakes himself to the court of the king. The court officers move to chase him away, but the king stops them. The Bodhisattva asks, "King, are you having all the dogs killed?" "Yes, I have ordered all the dogs to be killed". "What is their crime?" "They ate the leather trimmings of my carriage". "Do you know which dogs did that?" "No, I do not". "Then, O king, if you do not know which particular dogs ate the leather, it is surely not right that you have them all killed, wherever they are to be found". The Bodhisattva further asks the king if all the dogs in the kingdom are being slain or if some are being let live. The king replies that his own purebred dogs are being spared. The Bodhisattva admonishes the king; kings should not arbitrarily pass judgment. They should carefully investigate the situation and then weigh the facts as if on a balance and decide who is the guilty party. Instead the king has spared the powerful dogs and is killing the weak ones. The king asks the Bodhisattva if there is a way to find out who the culprits are. The Bodhisattva tells him to give his palace dogs an emetic and when the dogs vomit up the leather the king knows that they are the guilty ones. The king is impressed by the wisdom of the Bodhisattva, who then instructs him in the dharma. The king then grants freedom from harm to all living beings and orders that the dogs from now on all be fed with a meal fit for the king himself. The king then lives his life in accordance with the instructions of the Bodhisattva, making suitable gifts, and is reborn in heaven when he dies.

On the surface, it seems plausible to read this story as a template for a general injunction that one should feed dogs. But there are here, too, several features in the text that mitigate against such a reading. Most important is the framing of the story. We are told that the Buddha told this story when the topic of how the Buddha has helped his family came up, ñatatthacariyam àrabbha kathesi. ${ }^{26}$ Within the story, the dogs outside the palace are called his relatives, his ñati. He thinks to himself that he must save the lives of his relatives, "I must give my relatives the gift of life", ñätisanghassa jĩvitadānam dadeyyam, and he reassures "his relatives", ñatake samassāsetvā. At the end of the story the Buddha tells the monks, "It is not just now that the Tathāgata acted for the sake of his relatives; in the past he did that too, Na, bhikkave, tathāgato idāneva ñätakānam attham carati, pubbepi cariyevāti."

25 Aparo bahum pan̄itam pindạātam labhati. So tam cīvaram vìya theracirapabbajitabahussutaappalābhagilānānam datvā tesam

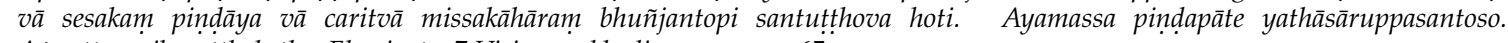
Añguttaranikāyațthakathā, Ekanipāta, 7 Viriyārambhādivaggo, para. $6 \overline{5}$.

26 Kukkura Jātaka, 22. 
There is another indication that this is the intended purport of the story. The opening passage mentions another Jātaka, the Bhaddasāla Jātaka 465, telling the audience that how the Buddha acted for the sake of his relatives will be clear in this later Jātaka. The Bhaddasāla Jätaka is a complicated account of the destruction of the Sākya clan. Three times the Buddha prevents their annihilation, but on the fourth opportunity to do so he finally lets it happen, knowing that he cannot change their karma. ${ }^{27}$ The Dog Jātaka is intended to offer an example in the past when the Buddha also acted in the service of his relatives. It is undoubtedly meant to be a story about helping your relatives and not about taking care of dogs.

There are, of course, many messages that may come through in a story. The verse gives us another important message, that it is wrong to spare the powerful and kill the weak. The Bodhisattva rebukes the king who would spare the dogs that were raised in the palace, purebred, endowed with strength and handsome, and slay the Bodhisattva's kin, the dogs who are powerless and weak. Surely there is no justice in this, he tells the king. And the Bodhisattva reminds the king of his duty as judge in criminal cases to carefully investigate a case before he pronounces a verdict and never to make snap judgments based on his own desires. The Bodhisattva, teaching the king the righteous way to behave, cites stanzas from another Jātaka, the Tesakuna Jātaka, 521. Among those verses is one verse that states that the king should behave properly with respect to animals and birds, dhammam cara mahārajja, migapakkhīsu khattiya (121). ${ }^{28}$ It follows verses on behaving properly towards mother and father, children and wives, friends and counselors, his army, villages and towns, kingdoms and territories, sramaṇas and brāhmanas. It is not, in other words, a lesson on non-violence or specifically about the treatment of animals. Indeed the phrase migapakkhi suggests animals and birds that are normally hunted by a king and may well refer to the kinds of restrictions of the royal hunt that are familiar from the Arthaśāstra. ${ }^{29}$

Another Jātaka that is often cited as advocating the feeding of a despised animal, in this case a crow, is the Kāka Jātaka, $140 .{ }^{30}$ In this story the Buddha has been reborn as a crow, living with other crows in the cemetery. One day two crows are sitting on the gate to the city. The king's priest has gone out of the city to bathe and decked out in clean finery is about to enter the city through that very gate. One of the crows tells the other, "I am going to shit right on his head". The other crow is appalled. He tells him, "Don't do that. This Brahmin is a god. And quarreling with a man who is a god is a sin. If he gets mad he can destroy all the crows". The first crow says he can't restrain himself and the second one beats a hasty retreat. The crow does the deed and the priest is furious. He plots the destruction of all the crows. In a somewhat tangled series of events, as humorous as the start of the story, an angry servant sets a goat on fire because the goat ate the rice grains she laid out to dry. The terrified goat extinguishes the flames by rolling in a pile of hay near the king's elephant stable and in so doing manages to start a fire that burns the king's elephants. The priest seizes the opportunity and tells the king that the elephants can only be cured by applying the fat of crows to their wounds. The king takes his advice and orders all the crows killed. The crows send a delegate to the Bodhisattva-crow to tell him of the danger to their lives. The Bodhisattva realizes that he alone can save his relatives. He flies into the king's palace and alights under the king's throne. When someone rushes to grab him the king orders him to stop. It is wrong, he says, to threaten a creature who has come to you for protection. The Bodhisattva explains to the king that it is not true that the fat of crows will cure the elephants; crows do not even have any fat, since they spend their days in fear and stress. The priest has only said this in order to take revenge on the crows. The Bodhisattva reminds the king that kings must not act rashly but must always act with due consideration. He establishes the king in the five sila or moral precepts and asks the king to grant all living beings safety. The king listens to

\footnotetext{
Granoff (2010), 'Karma', pp. 75-91.

Tesakuna Jātaka 521.

Arthaśāstra, 2.2;2.26. Translation, Olivelle, King, pp. 102-13; 157-58.

Schmithausen, 58 , note 56 .
} 
the Bodhisattva's discussion of dharma and grants the Bodhisattva's request. He also makes sure that food is regularly given to the crows, and to the Bodhisattva he gives a feast fit for a king.

This story, exactly like the story of the Bodhisattva as a dog, is told as a story of the past in which the Bodhisattva acted for the welfare of his relatives. In the introductory section, exactly as in the Dog Jātaka, the reciter refers to the Bhaddasāla Jātaka for the incident in the present that has prompted the telling of the past. The Bodhisattva, here too, refers to the other birds as his relatives, ñataka. This story, then, is not so much about saving birds as it is about protecting your own kind. In both of these stories it is worth noting that there is little in the Bodhisattva's behavior that we might associate with either a dog or a crow, making these stories seem less about animals and the animals really just an excuse to talk about human behavior in the mode of the famous collection of animal fables, the Pañcatantra, and of course, many of the other Jātakas. ${ }^{31}$

Some stories do indeed describe familiar animal behavior; in one Jātaka dogs are loyal to their masters and when taken away seize the first opportunity to return home. In the Sunakha Jātaka 242 the story of the present begins with some water carriers who had raised a dog from the time it was a puppy. The water carriers sell the dog to a villager for the price of an upper garment and a kahappana, clearly not very much. The dog willingly follows its new owner, who feeds him at every step. The new owner is convinced that the dog loves him and lets him off the leash. The dog runs right back to the water carriers. The Buddha tells the monks that this was not the first time the dog had gone back to his original owner and he tells the story of the past, at the time of King Brahmadatta, when the Buddha was a wealthy householder. There was a man who had a dog but then sold it to someone else. The new owner kept the dog tied up. When the Bodhisattva saw the dog tethered by a leather strap, he asked the dog why he didn't just eat through the leather and break free. The dog replied that he intended to do just that but was waiting for his new keeper to fall asleep. The Buddha explained to the monks that he was the person who had wondered why the dog wasn't escaping and the dog was itself. Except for the past dog's ability to speak in verse, both dogs behave very much as dogs might be expected to behave. They are loyal to their first owners; they can find their way back home, and they can be lured away by food. There is no lesson to be derived from this Jātaka about how to treat dogs, however; in fact, the original owners of the dogs, present and past, seem to have had no attachment to them and been willing to sell them to the first person who offered to buy them.

One of the most poignant stories of the loyalty of dogs that also highlights their remarkable ability to map territory is to be found in Buddhaghosa's commentary to the verses of the Dhammapada, book 2, story 1 , which is a sub-story in the larger cycle of stories about the famous king Udena. It also provides an explicit reference to a Buddhist ascetic offering food to a dog. In this story, a solitary Enlightened Buddha, a pratyekabuddha, feeds a dog every day from his alms. The dog is devoted to the pratyekabuddha and is sent by his master, a cowherd, to fetch the pratyekabuddha every day so that the cowherd can offer him alms. When one day the pratyekabuddha flies off to Gandhamādana, the dog looks up at the sky and howls. The dog dies of a broken heart, and the narrator of the story interjects, "Animals, they say, are straightforward and not given to deceit; men, however, think one thing in their heart, but say another with their lips. Therefore said the Exalted One to a monk, "The ways of men are past finding out, but the ways of the beasts are easy to discover". ${ }^{2}$

The quote is from the Majjhimanikāya, Kandarakasutta, which is a conversation between the Buddha, an ascetic named Kandaraka, and an elephant trainer. Buddhaghosa, in taking the quote from the Kandarakasutta, changes its meaning. The elephant trainer is not saying that animals are guileless; $u t t \bar{a} n a$ here means only that their wiles are transparent and easy to discover. This is why it does not take him long to figure out all the tricks and cunning ploys of the elephants. Men, on the other hand, he says, are deep and difficult to understand. It is impossible for an ordinary person to penetrate the

31 On the paucity of observation of animal behavior in Buddhist texts see (Deleanu 2000), 'Buddhist 'Ethology", pp. 79-127.

32 Burlingame, p. 255. 
many deceits and subterfuges that people employ. Only the Buddha can do this. His point is not that animals are pure, although this is how we want to read the statement when it is taken out of context in the Dhammapadatthakathā. The elephant trainer means to praise the Buddha; he himself as a trainer of elephants can understand only the few and simple tricks of elephants, while the Buddha knows everything about humans, with their myriad deceits. ${ }^{33}$

There are other stories of dogs who are close to humans. Again in the Dhammapadatthakath $\bar{a}$ we learn that Queen Mallikā had a beloved dog, vallabhasunakha. One day when she is in the shower the dog joins her and shows his affection in a way that she seems to enjoy but that disgusts the king. His behavior, one might add, is also questionable, since he appears to have been spying on his wife as she bathed. In the end she outwits her simple husband, accusing him of carrying on with a goat in the shower, but she later regrets her sinful behavior. ${ }^{34}$

Dogs, then, share the human landscape in many different ways, and in the stories they are often singled out for their loyalty to their human companions. But there seems to be surprisingly little evidence that taking care of dogs is a pious act. In the next section, I look at stories that are unmistakably about the merit of feeding animals or saving animals. Interestingly, the animal in question is a dog, and in many of the stories the dogs behave exactly as one might expect dogs to behave, they beg for food, wag their tails and attach themselves to people who show them kindness. The stories seemed exceptional to me when I first read them; while it is possible to cite a number of texts that prohibit doing harm to animals, calls for helping them seemed few and far between, although future study may well show that the stories I study here do indeed belong to a much larger category of writings. ${ }^{35}$ In addition given the strong prohibitions in the Dharmasūtras against allowing a dog even to look at Brahmins while they are eating, these stories seemed to go against the grain of normative behavior as it was defined in legal texts that had considerable influence in medieval south and southeast Asia. ${ }^{36}$

\section{Dogs as a Field of Merit}

The Pali Rasavāhinī of Vedeha Thera was composed in the later portion of the 13th century in Śrī Lankā. ${ }^{37}$ As the author himself states, his work is based on an earlier composition by Rațhapāla, which he does not name but which is assumed to be the Sahassavatthuppakarana, itself based on an earlier collection composed in Sinhala. The Rasavāhinī contains 103 stories, eight more than the Sahassavatthuppakarana; all but one has a parallel in the earlier text. The stories are divided into two sections, those that take place in Jambūdvīpa, and those that take place in Śrī Lañkā. Many of the stories are about dāna, and I have turned to this text because in several stories dogs are as much a suitable object for donation, a "field of merit", as are the usual recipients of donations, the Buddha, the monks, stūpas and monasteries. I begin with the story of Maruttabrāhmana, which is story 18 in the Nandiyarājavaggo of the Jambudīpuppati section.

The story begins on the banks of the Ganges, in a Brahmin village called Candabhāgā. A Brahmin named Marutta leaves the village for Takkasila to conduct some business. On his way back he finds a dog who is suffering from leprosy. Out of compassion he prepares a medicinal concoction for the dog and gives it to him to drink. The dog is cured, and aware of how much the Brahmin has done for him,

33 Kandarakasutta, MajjhimanikāyaYāvatakena antarena campaṃ gatāgatam karissati sabbāni tāni sāṭeyyāni kūṭeyyāni vañkeyyāni

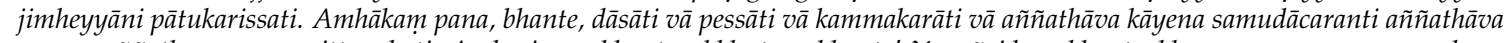
vācāya añ̃nathāva nesạ̣ cittạ̣ hoti. Acchariyam, bhante, abbhutạ̣, bhante! Yāvañcidaṃ, bhante, bhagavā evam manussagahane evam manussakasațe evam manussasāțheyye vattamāne sattānam hitāhitam jānāti. Gahanañhetam, bhante, yadidam manussā; uttānakañhetam, bhante, yadidam pasavo"ti.

34 Dhammapadatthakathā, Book 11 , story 6.

35 On injunctions not to harm animals from Jain texts see (Balbir 2009, 'Attitudes'. pp. 811-58).

36 Mānavadharmaśāstram, 3.239 and 3.241.

37 Matsumura (1992), The Rasavāhinī. This contains a lengthy introduction and translation of the fifth and sixth chapters. Matsumura also has a number of articles in Japanese on individual stories. See also Rahula (1984),'The Rasavāhinī', pp. 169-85. Text also online at http://www.tipitaka.org/romn. 
he follows him home. The Brahmin's wife becomes pregnant but when she is in labor the infant gets stuck in the birth canal and dies. To get the baby out they have to cut it into pieces. Seeing all of this, the Brahmin becomes disgusted with the life of the householder and sets off for the forest to become an ascetic. His wife takes up with another man, deeply angry at the Brahmin who had abandoned her to renounce the world. She tells her new lover to kill him. The dog overhears their conversation and joins the Brahmin. One day the lover sets out with his bow and arrow, determined to kill the Brahmin. The dog waits for a moment when the assassin is distracted and gnaws the bowstring. Each time the assassin fixes the string, the dog chews it up. Eventually the dog attacks the assassin, preventing the murder of the Brahmin. Thus, the storyteller comments, do good men repay the kindness done them. The Brahmin ascetic out of compassion tends his wounded adversary, perfects his meditative practices, and at the end of his life goes to heaven. A concluding verse urges us to exercise compassion and aid others. This, it says, is the cause of enjoyments in samsāra, bhavabhogahetu.

The ascetic in this story is not a Buddhist; he pursues the renunciation of non-Buddhist sages, the isipabbaja . The cause of his renunciation is a horrific mishap in childbirth; the dead baby must be dismembered to be removed from his wife's womb. While there is no doubt that the ascetic's achievement of jhāna or meditation contributed to his fortunate rebirth, the concluding verse suggests that it was also his assistance to the sick dog that brought about such an auspicious result. For his act of compassion to the dog, he is rescued from an assassin, given the opportunity to pursue his asceticism, and eventually he goes to heaven, to Brahmaloka.

In another story that also takes place in Jambūdvīpa, a man who earns his living by crushing sugar cane to make brown sugar, does a number of meritorious acts. ${ }^{38}$ The first is that he gives a sick monk a bit of ghee and another one a bit of brown sugar. The next day he comes upon a hungry dog and feeds him. He also honors a preacher of the Dhamma with a robe. He makes a wish that the merit that he accrues from these acts have this result: he asks that in every birth whatever he desires, in the ocean or on mountains, will come to be. He dies and is reborn as a god, and from that divine rebirth he is reborn at the time of Śākyamuni in Śrāvastī in a rich family. Realizing the pitfalls of the householder's life, he renounces and soon becomes an arhat. He takes his leave of the Buddha and with five hundred monks sets out for another town. Eventually he comes to a city that has a harbor. There he boards a boat with his five hundred monks. While at sea he gets a terrible stomach ache. The monks ask what he usually does for such an ailment and he tells them that in the past he would take a bit of ghee to cure his stomach. The monks are nonplussed; how are they to get ghee in the middle of the ocean, they ask. He tells them it is no problem; they are to take his bowl and fill it with seawater. As soon as they draw the water from the ocean it turns into ghee. The monks are suitably amazed. Our monk decides to put on more of a show for them and he turns the entire ocean into ghee and the mountains into brown sugar. And he makes bowls of food appear everywhere, and forests fill with clothes. He tells them that this is all the result of the merit he has done. The monk then explains what were the good deeds that he had done when a past Buddha, Kassapa Buddha, was alive. He tells about feeding the sick monks ghee and sugar, which has resulted in his getting ghee and sugar whenever, wherever he wants. And he tells how he fed a starving dog, which has resulted in his never lacking for food. In birth after birth food and drink, all he wants, have come to him, and even now, he tells the monks, he gets as much to eat as he has need of. The list of meritorious deeds continues, but it is clear that his feeding the dog has resulted in as great a result as his offering medicinal foods to the two sick monks. As he tells us, "A meritorious deed, no matter how slight, is not to be disparaged; it leads to endless results, even to nibbāna".

As the stories move to Śrī Lankā, we meet more householders and monks whose meritorious deed was to feed a starving dog. There is Abhaya Thera, who in a past life was named Deva and was in charge of a village that was associated with the monastery Pupphavāsa in the western region of

38 Saddhopāsakassa vatthu, yakkhavañcitavaggo, online text. 
Lankā. ${ }^{39}$ One day, exhausted and hungry after making his rounds, he stopped in a village and told his attendants that he needed to eat. They immediately brought food, but as soon as Deva was served, a starving dog, tormented by hunger and trembling all over, saw his food. Thinking that he might get a morsel to eat, the dog approached Deva. One of his attendants grabbed a stick and ran towards the dog to chase it away. Deva was filled with compassion and stopped him. He offered the dog a good amount of his tasty food and the dog ate eagerly. Seeing that, Deva felt content in his mind thinking about what he had done. As a result of the merit of that deed after he died he was reborn in a prestigious family. He grew up and renounced the world to become a monk. His monastic name was Mahābhaya Thera, "Great Abhaya Thera". The storyteller then explains, "If a person is content in his mind with what he has done, then even a gift to an animal will have a great result". There follow two verses: "Certain it is that the man who, with faith in his heart gives something to an animal, even to an ant, earns as a result of that gift the happiness of rebirth as a god or a human being, and in the end even achieves nibbāna".

The story continues with the account of a terrible famine that is the context for meritorious deeds or descriptions of their marvelous retributions in many of these stories. It was the time of the disasters wrought by Brāhmanatissacora. ${ }^{40}$ For twelve years it did not rain. There was great famine and anarchy, with thievery and looting. The people who lived near the monastery or vihära were no longer able to survive and decided that they would have to go elsewhere. They asked Abhaya to join them, but he would not abandon the relics of the Buddha that he worshipped every day. Thus Abhaya Thera stayed there alone, tending the stūpa and the Bodhi tree, with nothing at all to eat. On the third day, a god living in one of the trees, seeing the emaciated and starving Abhaya, turned to his wife and told her that it would be terrible if Abhaya starved to death; they must bring him something to eat. She asked her husband what Abhaya had done to deserve their assistance. He told her that the monk in a previous birth had been a man named Deva, in charge of the affairs of a monastery, and that when he was served food to eat, before he could even taste it, he noticed a starving dog, terrified and weak, and he had given the dog most of his food. That meritorious deed, the god explained, is now about to come to fruition. Even a small gift is not to be disparaged; a great banyan tree grows from a tiny seed. The god then took on human form and brought food to Abhaya. He told Abhaya to continue with his religious duties, free from worries, and that he would give him food every day. Abhaya should come to his abode, a Karañja tree, and Abhaya did just that. From then on, every day Abhaya went to the tree and the god gave him divine food to eat. Now one day a group of starving people, who in their desperation had resorted to cannibalism, approached the vihāra. They saw Abhaya there, plump and filled out from eating the divine food, and they decided to kill him and eat him. When the monk had finished sweeping the courtyard of the stūpa and was coming out they raised a hue and cry and with clubs and cudgels in their hands they rushed at him and surrounded him. Now, the monk in his previous life had stopped one of his attendants who had rushed at a hungry dog, stick in hand, and on account of that meritorious deed a huge mountain sprang up in the middle of the monastery. The mountain had a cavern in it and the monk entered that cavern and was saved. The people all thought that he must be an arhat and they took off. The monk, living on that divine food, spent twelve years as an unenlightened being and then achieved arhatship. As an arhat he lived there another twelve years. In this way, the god supported Abhaya for twenty-four years by feeding him divine food. Abhaya achieved nibbāna in that very monastery. The storyteller then concludes with these verses: Having given a hungry dog something to eat, the lord of ascetics attained divine food and peace and

39 This is how I interpret the phrase tass' āsanne Devagàme Devo nāma amacco tassa issaram vatteti, Matsumura p. 43. The Sahassavatthuppakaraṇa has pacchamapasse Pupphavāsavihāra bhikkhācārā-Devagāme Devo nāma amaccho ahosi. Sahassavatthuppakarana edition has numerous typos and mistakes. The Tịk $\bar{a}$ to, Nīvaranappahānavaggavannanāa, para. 16, glosses bhikkhācāra as follows: Bhikkhāya caranti etthāti bhikkhācāro, gocaragāmassetam adhivacanam, tasmim bhikkhācāre. "Bhikkhācăra refers to a place where the monks go to get alms; it is used to denote the village that is ear-marked for their begging rounds".

40 The unrest caused by the Brahmin Tissa and the Tamils is described in the Mahāvamsa, chp. 33. 
calm. You too should always give, no matter to what creature. It will serve you well from birth to birth and in the end bring you to nibbāna. ${ }^{41}$

This story is unequivocal in its assertion that feeding a starving dog is a meritorious act, as meritorious as any act, for it leads to the highest rewards: rebirth as a god or human and nibbāna. The story also stresses that the giver's mental attitude to the gift, after he has given it, is also important. Deva is pleased when he thinks about what he has done. The story makes its points in the narrative itself. Abhaya in a previous life had fed a starving dog and is now rescued in a time of famine; he is fed by a god and he is protected from starving people who would eat him. The storyteller reinforces this message with simple verses stating clearly that feeding an animal results in a great reward, divine and human happiness, and nibbāna. Abhaya reaps his reward at the time of a major famine that looms large in so many of the stories in the Rasavāhini and related collections and is also described in many of the Pali commentaries to canonical texts. It is a time when people have degenerated to the state of animals; indeed, one characteristic trait of animals in a wide range of Buddhist texts is that they attack and eat each other. ${ }^{42}$ I believe that the looming shadow cast by the Brāhamanatissa famine provides a clue to understanding the unusual praise for helping starving and sick dogs in these stories.

In the Rasavāhini, it is not only the stories about giving food to a starving dog that are set at the time of the Brāhmanatissa famine. The story V.10, Vatthulapabbata vatthu is an example. The story opens with a vivid description of the ravages of the famine. "At one time in the island Sinhala there arose the Brāhamatissa disaster, that lasted for twelve years. For all this time it did not rain on the island of Lankā. The crops failed and there was a terrible famine. Without proper food, people all began to get sick. Reduced to skin and bones, the people were in misery. The women in every house looked like demonesses and the men like hungry ghosts or goblins. At the door of every home people were crying, moaning in pain, and everywhere could be heard the sounds of people lamenting. The stinking bodies of the dead were piled up everywhere and their smell attracted hosts of ghouls. That too was a terrifying thing. Beset by so many disasters, the inhabitants of the island of Lanka fled to the mountains and rivers, somehow managing to survive". The story then moves to the main plot; a couple flee to Mount Vatthula, where they find a tree with three remaining branches. They plan to use the leaves on one branch for guests, on another for making gifts to people, and on the third, for themselves to live on. When a monk comes there and they wish to give him something to eat, they find to their great dismay that the leaves of all three branches have been devoured by insects. With their only food source gone, the wife decides to feed the monk with her own flesh and the husband is ready to join her. They are stopped from their rash act by the God Sakka, who provides food for them to offer the monk. ${ }^{43}$ It is in this environment, when people are all starving and turning to cannibalism, that the monk Abhaya in the story just reviewed is fed divine food because he had once fed a hungry dog. The reward for that deed must seem ever greater, given the dire circumstances that exist. ${ }^{44}$

The severity of the Brāhmanatissa famine and attendant disasters is described in a number of Pali sources. It resulted from a period of prolonged war, caused by a usurper and by an invasion of the Tamils. The Mahāvamsa chapter 33 verses $37 \mathrm{ff}$ only briefly describes the uprising and subsequent fighting. The would-be usurper, a Brahmin named Tissa, demands the throne from the reigning king Vatțagāmani, who assents on the condition that Tissa conquer the Tamils who are poised to invade Śrī Lankā. Tissa is defeated by the Tamils and what results is a period of anarchy and devastation throughout the kingdom. By contrast the destruction and famine are described in some detail in several of the Pali commentaries. The commentary to the Vibhanga, Nānavibhango has an account of

41 I am using Matsumura (1992), pp. 43-46.

42 Mahāvastu, opening section on Maudgalyāyana's visit to the animal world; Bālapandita sutta, para. 252.

43 Matsumura (1992), pp. 58-61.

44 The description of a famine so severe that people resort to cannibalism appears in a number of Buddhist texts. The Kärandazyūha describes a famine in Magadha, where people have taken to eating each other. Avalokiteśvara produces food for them. Kārandavyūha 1, 16, Magadhabhramanam. 
the monk, Mahāsonathera that is similar to the story of Abhaya in the Rasavāhinī. ${ }^{45}$ As the account of Mahāsonathera opens, the monks in two major monasteries are struggling to survive; rats have eaten all their food and there is nothing left for them. The monks at Cittalapabbata decide to leave their monastery for Tissamahāvihāra, hoping to find food there. The monks at Tissamahāvihāra decide to leave for Cittapabbata to find food there. The two groups, twelve thousand strong, meet mid-way, and learning that there is nothing to be had anywhere, they sit in meditation and achieve nibbāna in a forest. Later, when the famine is over, others will make a stūpa for their remains. The entire island is devastated and most of the monks decide that they cannot stay. They build a raft and set sail. Mahāsonathera and two other monks, Cūḷasivvathera and Isidattathera, remain behind. Cūlasīvathera is initially fed by a tree deity, and here the parallel to the story of Abhaya is clear. The deity leads him first to an abandoned monastery and then to a village where the people are subsisting on leaves. Mahāsonathera and Isidattathera stay alive by eating what others have discarded, the skin of fruits or stalks of lotuses. They are eventually supported by a lay couple who give them food that consists of nothing more than the bark of the coconut tree mixed with some plant fibers. Isidattathera remarks that this is a time of dire scarcity, during the chaos and famine created by Brāhmanatissa, and at a time like this even a paltry gift of barely edible food will bring great reward when the time is right. ${ }^{46}$

So devastating were the ravages caused by the evil Brāhmanatissa, that in some accounts they were considered a threat to the very survival of Buddhism. In a passage on the disappearance of Buddhism, Buddhaghosa stresses that the scriptures, the pariyatti, are the very foundation of the community, the sāsana. This was the reason why, he tells us, that at the time of the disasters caused by that wicked outcaste candāla Tissa, the god Sakka intervened. Sakka made a raft for the monks and warned them that at this time of famine they would be unable to meet their basic needs, and unable to meet their basic needs they would be unable to study and memorize the Buddhist texts, the three baskets or Tepitaka and their commentaries. He urged the monks to crowd onto the raft and sail across the ocean where they would be able to survive. ${ }^{47}$ The famine and chaos of the Brāhmanatissa years left a profound impact in the commentarial literature as well as our stories. Indeed, at the time the Rasavähini was being composed in the 13th century, the island was subjected to repeated attacks from South India, so severe that the capital had to be moved from Polonaruva. ${ }^{48}$ The frequent mention in the stories of the ravages of Brāhamanatissa may even reflect contemporary suffering.

The next story from the Rasavāhinī that I discuss is about Puvvapabbatavāsi Thera, the monk who lived on East Mountain. It does not take place in a time of famine but again describes the great rewards of giving food to a hungry dog. The monk who gives his food to the dog is himself hungry. Hunger remains pervasive. At the time of the Buddha Kassapa there was a merchant who went from village to village peddling red arsenic powder. In one village a young woman called him over and bought some of the powder. He told her he was hungry, and she gave him a splendid dinner of fine rice and a curry of peacock meat with ghee. But before he could eat he saw a dog, overcome by hunger, trembling, sick from starvation. Seeing that suffering dog, filled with compassion, he gave the dog much of the rice mixed with peacock meat and oil. The dog ate the food, and happily wagging his tail, he stood there in front of the merchant. Seeing that, the merchant felt content, and he made a wish that from the merit he earned by feeding the dog, in every birth he wanted to eat peacock meat and ghee. He is reborn numerous times as a human being and eventually becomes a monk. He retains the connection to his gift to the dog. His begging bowl is always filled with peacock meat curry. An officer hears about the monk with the peacock curry and decides to see if it really is true that he always gets peacock meat in his bowl. He tells his wife to make some meager meal and invites the monk. A god

45 The parallel is noted by Matsumura (1992), cxxxviii.

46 Sammohavinodin̄i, Vibhañga commentary, Ñānavibhañgo, para. 810. In his Alagaddūpamasutttavaṇanā, Majjhimanikāya he also mentions a time when because of famine or danger, sūtra reciters are no longer able to stay together.

47 Manorathapūraṇī on Añguttaranikāya, Ekanipāta, 10, Dutiyapamādādivaggavaṇnanā.

48 (Blackburn 1999), 'Magic in the Monastery', p. 360. 
hears of this and he has his own wife supply the ingredients for fine peacock curry. The officer realizes that this was the act of some deity and that the monk must have done something greatly meritorious in a past life. (VI.3). When the monk is on his death bed and all the other monks have gathered, he explains what he did to merit his miraculous feasts of peacock meat. In a past life, at the time of Kassapa Buddha, he was an itinerant merchant who sold red arsenic powder. A woman took pity on him when she realized how hungry he was and fed him with fine rice, peacock meat and ghee. But he fed it to a starving dog and made a wish. From the merit he gained by feeding the dog, he was reborn in heaven, where he enjoyed divine pleasures in a jewel-palace. He was delighted with the dances and sweet songs performed by heavenly maidens. When his life in heaven was over, he was reborn five hundred times among humans. He was always born in a highly respected and wealthy family, much honored by his relatives. And in each of those five hundred births he ate peacock curry. Now in this, his last birth, he always got peacock curry in his alms bowl. All of this was the result of that one deed, feeding the hungry dog. In his final statement before he dies he tells his fellow monks, "The person who gives, even to an animal, will like me in every rebirth experience divine pleasures". The narrator concludes, "And hearing his final words, people performed meritorious acts like giving and they all went to heaven" ${ }^{49}$ A gift of food to a starving dog results in life-times of pleasure and abundance.

It is not only the person who feeds the dog who gains great merit in this collection; in another story, it is the dog who first gains an excellent rebirth and then in that rebirth encounters her benefactor again and reminds him of their connection. He too ultimately reaps the reward of his kindness to the dog. ${ }^{50}$ The story begins in Śrī Lankā, where a monk named Tissa lives in a monastery of the same name, the Tissavihāra. One day on his rounds he manages to get just enough rice for himself to eat along with a bit of ghee. He is directed by the villagers to a quiet forest spot where he can get fresh water and eat his alms. There in the woods a miserable starving dog has just given birth and is lying near her pups. When she smells his food, she gets up, and trembling all over, she approaches the monk, wagging her tail. When he sees her, he feels compassion for her and gives her the first handful of food from his bowl. ${ }^{51}$ Seeing how happily she eats what he has given her, he continues to offer her the rest of his food. The dog, filled with feelings of devotion and affection for the monk, dies and is reborn in India, in Jambudvīpa, in the womb of a queen. She grows up in luxury. When sixteen years have passed, the monk Tissa decides to make a pilgrimage to Bodh Gayā to worship the Bodhi tree. Once there, he sets out on his begging rounds. The princess sees him and remembers her past birth. The narrator interjects that she had once in a past life been a nun and had made a donation of oil for a lamp and a book along with leaves to write on and a stylus. She had made a wish that in her next birth she wished to have the ability to remember her former births. And so, she recognizes the monk as the monk who had fed her when she was a starving dog. She reminds him of their shared past and tells him that because of her feelings of devotion to the monk, in this birth she has been reborn as a princess. She reflects that if the reward for devotion to a monk is so great, how much greater must the reward for devotion to the Buddha be. She has a monastery or vihära built for the monk, who recalling with contentment his gift of food to the dog, and meditating on the Buddha, soon becomes an arhat. Eventually he dies there in the vihāra she had built for him and achieves nibbāna.

The story has its inconsistencies, most notably in the interjection that the princess had once been a nun and as a result of her pious deeds in that birth now remembers her past births, and we may suspect here a problem with the text, for this comment makes little sense in a story of a starving dog that directly became a princess. A close parallel to this story is told in the Sinhalavatthuppakarana, and no explanation is provided for why the young girl can recall her past birth as the dog. There are some slight differences between the two stories; in the Sithalavatthu version, the dog is reborn not as a princess

\footnotetext{
(Matsumura 1992, pp. 77-81).

Rasavāhinī: A Stream of Sentiments, story IV.10, pp. 163-66.

The text uses the word a lopa. See my earlier comments and note 6 .
} 
but as the daughter of a wealthy merchant. We also learn how the dog died; right after it ate someone beat it with a stick to chase it away. And it is not the monk who fed her who goes on the pilgrimage, but a group of monks from his monastery. She tells them her story, gives them gifts and sends them back to Lankā with a message for the monk who had helped her. ${ }^{52}$ But in both texts, the story of a monk feeding a starving dog is turned into a story extolling both the gift of food to the dog and the merit one gains from having feelings of devotion to a monk. They are equal. In the Rasavāhini the story of the dog who becomes a princess is the last story in the section on Jambūdvipa and in its own way serves as a link to the section on Śrī Lankā that follows, for it starts out in Lankā and ends up in Jambūdvīpa, linking the two countries by the monk's pilgrimage.

\section{Charity in a Time of Famine}

We have, in the stories of the Rasavāhini, come a long way from the very guarded approval of giving to an animal that appeared in the passage from the Dakkhināvibhanga sutta of the Majjhimanikāya that I cited at the start of this paper. We may recall that this was the lowest form of fourteen types of gifts, and its merits lasted the shortest period of time, only one hundred years. ${ }^{53}$ In the Rasavāhini the positive results of the gift of food to a starving dog lead even to the highest goal of all, nibbāna. Why, it seems natural to ask, do these stories stress the great rewards for a gift that was not highly praised in other texts? The Vibhanga commentary that tells the story of Mahāsona and discussed above may provide a clue; even a gift of food that is hardly edible at the time of the Brāhmanatissa troubles, Isidattathera proclaimed, will ultimately have a great reward. There is something different about the time of the famine for the calculus of merit.

The idea that a gift of food made at a time of famine is particularly meritorious is familiar from a wide range of Buddhist texts. In fact, such times of disaster offer special opportunities to make merit. A Buddhist story in an early Sanskrit collection, the Divyāvadāna, story 10, about the righteous householder Meṇhaka offers effusive praise of simple acts of charity done at a time of great need. The story is set in Banaras, at the time of King Brahmadatta. The kingdom is prosperous; there is plenty of food for everyone; people live in harmony and there are no thieves; the crops and livestock flourish. The king looks after his subjects as a father looks after his children. But despite all these things, which are in themselves all signs of the righteousness of the king, an astrologer comes and predicts that there will be a drought that will last twelve years. The narrator explains that there are three types of famine; cañcu, śvetāsthi and śalākāvrtti. ${ }^{54}$ Here is how he describes these. During the first type of famine people put seeds into a container for others to use in the future. In the second type, people gather the bones of the dead and boil them until they turn white. They then drink the broth. In the third type of famine, people use sticks to dig holes in search of grain and then boil the grains in a large pot of water and drink the broth. The 4th century scholastic commentary of Vasubandhu, the Abhidharmakośabhāssya 3.99 explains each of the three types in two ways. For the first one it says that the word cañca can mean either "together" or a "container"; taking the first meaning, the famine is so called because everyone together dies of starvation; taking the second meaning, starving people store some seeds in a container for those who will come after them. To the definition of the second one, the white-bone famine, it adds that the starving people are all bones. And to the third one, "eating by tickets", it adds this: since there is not enough food in the house for everyone to eat, people take turns, the father eating one day, the mother, another day and so on. Its second explanation is close to what is given in the Divyāvadāna; people use the tickets, which are sticks of wood, to dig out bits of grain from where the grain is stored and then boil what they are able to get in lots of water. The Abhidharmakośabhāsya

52 Le Sìhalavatthuppakarana, story 3, pp. 93-95.

53 The sutta describes the gift to an animal as sataguna, "having a hundred good qualities or being a hundred-fold", which Buddhaghosa glosses as having its reward lasting over one hundred births, attabhāvasate āyum deti, vannam, sukham, balạ̣, patibhānam deti, nipparitasam karoti. Dakkhināvibhañgasutta, para. 379.

54 Divyāvad̄āna 82. pp. 16-21. 
describes these famines as part of its description of the end of the world-age, when everything will be destroyed. There is nothing that can be done to avert this famine; it must run its course. ${ }^{55}$ By contrast the Divyāradāna story has a more positive message. King Brahmadatta tells his subjects that those who have enough grain stored for twelve years should remain; everyone else should leave the city. Mendhaka asks the keeper of his stores if there is enough for twelve years and he assures him there is. He stays with his wife, his son, his daughter-in-law and a male and female servant. As the famine drags on his stores are exhausted. Except for his family and two servants, everyone else who remained in the city is dead. Meṇhaka has only one last measure of grain, and as he gives it to his wife to cook, a pratyekabuddha comes to his door asking for alms. He knows that if he gives up the food he will die, but still he gives his portion to the pratyekabuddha. His wife, son, daughter-in-law, and servants do the same with their portions and each makes a wish that their gift will grant them something special. Mendhaka and his wife wish for the ability to fill everyone's empty storehouse with grain and that what they cook in a single pot will be enough to feed thousands. All of this they are granted as soon as they make their wishes. The king learns of this and is astonished that the gifts they made to the pratyekabuddha brought so much merit that their reward was instantaneous. The story makes it clear that it was not only the worthiness of the recipient, the pratyekabuddha, that made the gift so special; it was also the occasion, a time of dire scarcity.

In another early collection of Buddhist stories, the Avadannaśataka, IV.32, the Buddha in a past birth was a king who gave his last morsel of food to a Brahmin and then to the god Indra, who had come disguised as a Brahmin to test him. We do not know the cause of the drought in this story, but the story does tell us that Sakka (Indra) was so impressed with this gift that was no ordinary gift, so difficult was it to make, that he promised to send the rain. Stories like these suggest that the circumstances of the gift, a time when people are suffering, make the gift particularly precious. Charity given in time of the greatest need, in a time of mass suffering, is uniquely praiseworthy.

The same constellation of beliefs is reflected in Jain stories. The Jain monk Hemacandra (1088-1173 CE) in his Trișaștiśaläkāpurusacarita, an account of all the Jinas and Jain culture heroes, has a brief biography of Sambhbavanātha, the third Jina of our world age. ${ }^{56}$ It gives only one of his past births, in contrast to the biography of Pārśvanātha, for example, which describes that Jina's nine past births. Sambhavanātha in a previous birth was a king Vipulavāhana. He was a righteous king and cared for his subjects as a gardener tends his garden (5). If he punished the wicked, it was like a doctor, proffering medicine to the sick (8). The Jina, the Omniscient God, was always present in his mind, just as he is present in a temple, and his words, like the Jain scriptures, always praised the virtues of the Jina (11). He bowed his head to the Jina, his god, and to his pious guru; all the others on this earth bowed to him (12). He reaped the highest fruit of having mind, speech and body by using them for proper meditation, recitation of the scriptures, and worship of the Jinas (13). All the twelve vows of the lay Jain were firmly fixed in him, just as indigo stays fixed forever on a cloth (14). He devoted his wealth to making donations for images, shrines, copying of scriptures and support of the Jain community of monks, nuns, laymen and women (16). In his compassion, he supported the poor and the abandoned. None went away from him empty handed, as a cloud never leaves the ocean empty of water (17). But despite his piety, generosity and righteous behavior, a terrible famine befell his kingdom, for it is impossible to avoid what is fated to be (20). The text describes in detail the ravages of the famine. The rain clouds that should have darkened the sky did not appear and the rainy season was like a second fierce hot season (21). Scorching winds blew, drying up all the ponds and uprooting trees, like the winds that roar at the end of time (22). With no food to eat, the people were like ascetics, subsisting on the bark of trees, and roots and fruits (24). Ashamed to beg, people

55 Abhidharmakośabhāsya, 188/08-17. The association of the end of the world cycle with a massive famine appears in Brahmanical texts as well. An early example is the Yugapurāna, dated to the 2nd c CE, which describes in some detail the twelve-year famine at the time of the Kali Yuga.

56 Triśaștiśalākācarita, 257. 
disguised themselves as ascetics and roamed around in search of food (26). Fathers, mothers, children, all abandoned each other, wandering aimlessly as if lost (27). As his son looked on crying piteously from hunger, a father kept for himself the food he had somehow managed to find (28). A mother, wandering the streets, sold her own son for a handful of chickpeas; in the early morning beggars, like house pigeons, scooped up the grains that fell to the courtyard from the mansions of the wealthy (29-30). The main streets of the city were worse than cemeteries, with beggars, nothing but bones, lying there right where they fell (33).

King Vipulavāhana, the future Jina Sambhavanātha, was deeply moved by the suffering of his people. He gave out food to his starving subjects, for as long as the famine lasted. The text tells us that it was through this act of supporting the Jain community during the famine that the king acquired the karma that determined that in his next birth he would become a Jina (48). There could be no greater proof of the importance of giving in a time of disaster than this story of King Vipulavāhana. King Vipulavāhana's story is distinctive in that his generosity is directed not to a lone holy man, pratyekabuddha or Brahmin as in the Buddhist stories, but to everyone who was in need.

These narratives are not the only evidence we have that giving at a time of famine was regarded as a uniquely virtuous act. We are fortunate in having compositions by Jain monks that describe historically documented famines and praise the generosity of Jain lay donors.

One famous medieval donor was the Jain merchant Jagadū, whose story was told by a Jain monk named Sarvānanda in the 13th century. ${ }^{57}$ Jagadū was a wealthy merchant in Kutch. His business dealings included maritime trade with the Middle East. He is helped by some extraordinary luck and a willingness to pursue his own advantage in acquiring his wealth, something I have discussed elsewhere. ${ }^{58}$ But whatever we may think of the means by which he acquired his wealth, there is no doubt that Jagaḍu uses it for good. In chapter 6, verse 66 of the poem, a Jain monk named Paramadeva, who is knowledgeable in all the scriptures, takes Jagadu aside and tells him that in the year 1321 (1265 CE) there will be a terrible famine that will last for three years. He advises Jagadū to send trusted retainers to all the different lands and have them collect all the grain they can get hold of (68). The monk adds that doing so, Jagadū will acquire fame as spotless as the waves in the white milk ocean by saving every living being, in every land (69). Hearing those words of the Jain monk, Jagadu agrees to do as the monk has said. He thus sends his emissaries everywhere and has them buy up all the grain (71). When the year the monk had specified arrives, everywhere on earth the clouds fail to give rain (72). Jagadū, in his compassion, begins to give grain seeds to the people who are suffering in the famine (73), and to some he has his men distribute grain. When two years of the famine have passed, the storehouses of the kings in all the lands are exhausted and the prices for grain soar (76) Summoned by the king of Gujarat, Jagadū gives him a reserve of grain that he had saved for the starving (88). Thus does Jagadū rescue the entire world from the terrible famine. There follows a long set of verses praising his generosity and foresight, that leave no doubt that his aid to the suffering at the time of the famine was a deed of the incomparable merit. He is likened to the god Kṛnna, who destroyed the pride of the serpent Kāliya, for he destroyed the might of the Kali age. The one who nurtured the entire world, he is said to be the very bark of the creeper of dharma (91). The poet asks, what kind of fame did the god Viṣnu get from casting the demon Bali into the underworld, or Śiva, for that matter, in burning up the god of love, husband of the goddess Rati? True fame belongs only to Jagaḍu, who destroyed the famine that was threatening the entire world (92). And another bard sang his praises in this way:

"Let the god Brahmā, abandoning everything else, meditate on the highest reality;

Let Śiva give himself over to embracing the daughter of the Mountain Himalaya.

57 Jagadūcaritam Mahakāroyam chps. 6, 7 deal with the famine.

58 Granoff (2017), 'How to make and spend money'. 
Let Viṣnu sleep on the ocean, having taken the goddess Lakṣmī in his lap. Who needs them when there is Jagadiu, ready to save the world! (93)

We might call Śakra and others world protectors, but in truth, there is only one person who protects the world, and that is Jagadiū!" (95)

A series of verses lists the names of the various kings to whom Jagadu gave grain. They include Hindu and Muslim rulers. The verses praising Jagadū continue even into the next chapter, when it rains and the cătaka birds who live on rain again sing his praises.

Perhaps the most unusual account of a famine in all of Indian literature was written by another Jain monk, Samayasundarasūri, who lived from 1553-1645. Samyasundarasūri was a prolific writer who wrote in several different languages. Jain monks were often praised for their linguistic gifts; as wandering ascetics who preached to many different groups in many different places, Jain monks were adept in speaking and writing in multiple vernacular languages. Samayasundarasūri's Satyāsiñ $\bar{a}$ Dukāl Varnan Chattīsī, "Thirty-six verses on the Famine of the year 87", is written in a language that is closest to a medieval Hindi in its grammar, but not in its vocabulary, which presents a challenge to the modern reader. It describes in vivid language a famine to which the monk was an eye witness. ${ }^{59}$ The famine took place in the year VS 1687, or 1631 CE. There are a number of accounts of this famine in Dutch and British sources. The famine was centered in the Deccan and Surat, and it produced widespread suffering, economic disruption and a massive movement of populations from areas of scarcity. Samayasundara's poem seems to be the only account of this great famine that we have that was written by an Indian and written in an Indic language. ${ }^{60}$

Samayasundara begins his poem by describing the greatness of Gujarat and its prosperity. We are reminded of the Buddhist Divyāvadāna description of Benaras before the famine and the Jain description of King Vipulavāhana's reign before disaster strikes. In Samayasundara's opening verse, Gujarat was a land where righteousness prevailed and people had plenty to eat. They enjoyed good health and to everyone who lived there the place seemed like heaven itself. There were lofty mansions and people had lakhs of money to spend building such palatial homes. Wives adorned themselves with costly jewelry. It is in the midst of all this prosperity that the terrible misfortune of the famine of 87 struck. As if to emphasize that no human agent was responsible for the disasters that the famine caused, Samayasundara in the concluding line to each verse addresses the year of the famine directly with words of rebuke while the famine raged, and words of warning as it ebbed. For example, after a description of the chaos that the famine was causing, with Hindus becoming Muslims and Brahmins being destroyed, with holy men made to suffer and everyone oppressed by hunger, Samayasundara calls out, "O, Year 87, the sin of all this is yours forever" (12). In another verse, the poet describes how countless people have died and their swollen corpses lay in the streets, giving off a horrible stench. In the last line he turns to the famine year and asks, “O Year 87, tell me, in whose house was there no crying to be heard? (18). This literary device of addressing directly the famine year, rather than any human agent responsible for the disaster, impresses on us both the arbitrariness and severity of the suffering that the poem describes.

The year 87 was a year without rain. Where rain fell at all it was too little. Fields and wells dried up. Samayasundara describes vividly the social dislocation: people began to resort to looting and took to the road (5). He stresses that none of this was the fault of the king. The king was a good king and protected the earth as a father protects his children. He looked on his people with affection, but once the famine began human actions did make it worse. There were those who became greedy (6). There was widespread hoarding and price gauging; Samayasundara even gives us the figures of what some foodstuffs came to cost (7-8). Decent men were reduced to begging, abandoning all vestige of shame, but still they could not fill their bellies (8). Sons abandoned their fathers and fathers their sons;

59 Samayasundara-Krrti-kusumā̃anjali, pp. 501-15.

60 Some hagiographies of Hindu saints in Gujarat also describe terrible famines; there it is not the generosity of the donors that is praised but the miracle-working powers of the saint, Wood (2015), 'Jalarām Bāpā' p. 116. 
brothers and sisters abandoned each other. People fled their homes and sought refuge in places strange to them (9). Fathers sold their sons; gone was respect for decency and religious norms; people sold everything they had, books, clothes, their kitchen vessels (13). Lay Jains no longer observed the rituals of confession and all the temples stood empty; there were no sounds of the songs praising the Jinas. The students no longer recited the scriptures, their mouths were too dry from hunger (15). Among those who died Samayasundara names several Jain monks.

But all of these descriptions of suffering are only a prelude to the long section of the poem in which Samayasundara names individually and praises all those who came to the aid of the suffering. These men, like the 13th century merchant Jagadū, opened their grain storehouses and gave generously of whatever was needed. They struck back at the famine with their acts of charity. The famine eventually recedes, and for Samayasundara it was these virtuous donors whose pious acts brought it to an end. If human wrongdoing did not cause the famine to begin, in Samayasundara's poem human decency definitely causes it to end. For it was the generosity of the donors that moved Indra, the god responsible for rain, to act. Sitting in his Sudharma heaven, Indra orders the year 88 to descend to the earth and bring rain. The famine that had caused innocents to die is over and life returns to normal. The sounds of sutra recitation are heard again, and monks resume their religious practices. The acts of charity that Samayasundara details were of such great power that they even moved Indra to intervene.

With all of these accounts in mind, we are ready to return to the Rasavāhini and the stories about feeding starving dogs that were often set in a time of a great famine.

\section{Conclusions}

The stories in the Rasavanhini reinforce what was clear from the story discussed earlier from the commentary to the Vibhanga, namely that there is something different in the calculus of merit at a time of famine. Even a paltry gift of food brings great merit. And the Jain stories add to this that the person who saves others from hunger during a famine is greater than any of the gods; the single act of feeding the starving masses leads a king to bind the karma that determines he will gain Liberation and become a Jina in his next life. In the Rasavāhini even feeding a starving dog leads to the ultimate goal of nibbāna.

I suggest the stories in the Rasavāhini belong to this broader context of stories of the great merits of charity at a time of famine. In these stories it is not only the hierarchy of the objects given that is upended; the hierarchy of recipients is also altered. The lowest in the normative scheme, a dog, is now a field of merit as important as a monk, a pratyekabuddha, a stūpa, or even the Buddha himself. In the literary imagination and perhaps also in reality, so great was the human suffering, and so brutally were the boundaries between human and animal eradicated as humans lived on leaves, in mountains and by rivers, and ate each other to survive, that praising the act of feeding of a starving animal becomes a way once more to separate the human from the animal and restore the dignity of being human. Perhaps, too, in the widespread suffering from hunger it was not difficult to empathize with another emaciated, hungry creature. Suffering could forge a new understanding of commonality and belonging.

Funding: The conference at which it was originally given was funded by the Glorisun Global Network for Buddhist Studies.

Conflicts of Interest: The author declares no conflict of interest.

\section{References}

\section{Primary Sources}

Abhidharmakośabhāṣya. GRETIL. Available online: http://gretil.sub.uni-goettingen.de/gret_utf.htm (accessed on 10 June 2017; 28 August 2017).

Agarchand and Bhanwarlal Nahta, eds. 1956. Samayasundara-Kṛti-kusumāãnjali. Abhaya Jaina Granthaamālā 15 Calcutta: Nahta Brothers. 
Alagaddūpamasutttavaṇnanā, Majjhimanikāya, Opammavaggo. Available online: http:/ /www.tipitaka.org/romn/ (accessed on 17 May 2018).

Arthaśāstra. GRETIL. Available online: http://gretil.sub.uni-goettingen.de/gret_utf.htm (accessed on 17 March 2018).

Avadānaśataka. GRETIL. Available online: http://gretil.sub.uni-goettingen.de/gretil/1_sanskr/4_rellit/buddh/ avsata_u.htm (accessed on 7 August 2017).

Bālapaṇitia sutta, Majjhimanikāya, Uparipaṇnāsa, Suñãatavaggo. Available online: www.tipitaka.org/romn (accessed on 29 June 2017).

Bauddhāyana Dharmasūtra. 1999. GRETIL. Translation Patrick Olivelle. Oxford: Oxford University Press. Available online: http:/ / gretil.sub.uni-goettingen.de/gret_utf.htm (accessed on 25 June 2017).

Bhaddasāla Jātaka 465. Available online: http:/ / www.tipitaka.org/romn/ (accessed on 15 June 2017).

Bodhisattvabhümi. GRETIL. Available online: http://gretil.sub.uni-goettingen.de/gret_utf.htm (accessed on 26 June 2017).

Bṛhatsaṃhitā. 1946. With an English Translation by Panditabhushana V. Subrahmanya Sastri. Bangalore: V.B. Soobbiah and Sons.

Cetanāsuttavaṇnanāa, Ainguttaranikāya, Catukkavaggo, Sañcetaniyavaggo. Available online: http://www.tipitaka.org/ romn/ (accessed on 12 March 2018).

Dakkhināvibhañga sutta, Majjhimanikāya, Uparipaṇnāsapāli, 4 Vibhañgavaggo, 12. Available online: http://www. tipitaka.org/romn/ (accessed on 26 June 2017).

Dhammapadaț̣akathā. 1995. Translation Eugene Watson Burlingame, Buddhist Legends, Harvard Oriental Series 28 Eugene Watson Burlingame, Buddhist Legends, Harvard Oriental Series 28. Oxford: Pali Text Society. Available online: http:/ / www.tipitaka.org/romn/ (accessed on 6 July 2017).

Divyavadāna. GRETIL. Available online: http://gretil.sub.uni-goettingen.de/gretil/1_sanskr/4_rellit/buddh/ divyav_u.htm (accessed on 27 August 2017).

Iṇasutta, Añguttaranikāya. Chakkanipata, V. Dhammika Vagga, Sutta 45. Available online: http:/ /obo.genaud.net/ dhamma-vinaya/pali/an/06_sixes/an06.045.pali.bd.htm (accessed on 25 June 2017).

Jagadūcaritạ̣ Mahakāoyam. Ahmedabad: Bhadrankar Prakashan, 2009.

Kandarakasutta, Majjhimanikāya, Majjhimapaṇn̄āsapāli, Gahapativaggo. Available online: http:/ /www.tipitaka.org/ romn/ (accessed on 6 July 2017).

Kāraṇavyūha. GRETIL. Available online: http://gretil.sub.uni-goettingen.de/gretil/1_sanskr/4_rellit/buddh/ bsu019_u.htm (accessed on 6 July 2017).

Kukkura Jātaka, 22. Available online: http:/ / www.tipitaka.org/romn/ (accessed on 26 June 2017).

Mahākarmavibhanga. GRETIL. Available online: http:/ / gretil.sub.uni-goettingen.de/gret_utf.htm (accessed on 15 June 2018).

Mahāvaṃsa. Available online: http:/ /www.tipitaka.org/romn/ (accessed on 17 April 2018).

Mahāvastu. GRETIL. Available online: http://gretil.sub.uni-goettingen.de/gret_utf.htm (accessed on 28 June 2017).

Mānavadharmaśāstram. 1886. Edited by Viśvanātha Maṇdalika, Bombay: Nirnaya Sagara Press.

Manorathapūraṇī. Available online: http:/ / www.tipitaka.org/romn/ (accessed on 4 July 2017).

Nīoaraṇappahānavaggavaṇnanā țīkā Ainguttaranikāya Ekanipāta. Available online: http:/ / www.tipitaka.org/romn/ (accessed on 6 July 2017).

Patrick Olivelle. 2013. King, Governance, and Law in Ancient India: Kauțilya's Arthaśāstra. Oxford: Oxford University Press.

Puttamāmsūpamasutta, Samyuttnikāya, Nidānavaggo. Available online: http://www.tipitaka.org/romn/ (accessed on 13 March 2018).

Rasavāhinī: A Stream of Sentiments, Transcribed into Roman from the Simhalese by Dr. (Mrs.) Sharada Gamdhi. 1988. Delhi: Parimal Publications.

Saddhopāsakassa vatthu, yakkhavañcitavaggo. Available online: http://www.tipitaka.org/romn/ (accessed on 27 June 2017).

Sahassavatthuppakarana. Edited by Dr. Mrs. Sharda Gandh.Ghazibad: Indo-Vision Private Limited, 1991.

Sāmañ̃aphala sutta, Dīghanikāya. Available online: www.tipitaka.org/romn (accessed on 29 June 2017).

Sammohavinodinī. Available online: http:/ / www.tipitaka.org/romn/ (accessed on 27 June 2017). 
Śikșassamuccaya. GRETIL. Available online: http://gretil.sub.uni-goettingen.de/gret_utf.htm (accessed on 27 June 2017).

Sonasutta, Añguttaranikāya, pañcakanipāta, Brāhmanavaggo. Available online: http://www.tipitaka.org/romn/ (accessed on 17 July 2017).

Rājā Rudradeva of Kumaon. Śyainika Śāstra, or, A Book on Hawking., edited with an English Translation by Mahāmahopādhyāya Haraprasāda Shāstri. Calcutta: Asia Society, 1910.

Tesakuna Jātaka, 521. Available online: www.tipitaka.org/romn (accessed on 26 June 2017).

The Yuga Purāna. 1986. Edited by John E. Mitchiner. Calcutta: The Asiatic Society.

Theragāthaț̣nakathā Timsanipāto, Sāriputtattheragāthāvannanāa. Available online: http:/ / www.tipitaka.org/romn/ (accessed on 4 July 2017).

Therīgāthā, Mahānipāta. Available online: http:/ / www.tipitaka.org/romn/ (accessed on 20 July 2017).

Triśaștiśalākācarita. 1990. Edited by Munirāj Punyavijayajī, Ahmedabad: Kalikālasarvajña śrīHemacandrācārya nava Janmaśatābdī Smrti.

Valähakassajātakavannanā, Jātaka 196. Available online: http:/ /www.tipitaka.org/romn/ (accessed on 26 June 2017). ver Eecke, Jacqueline. 1980. Le Sïhalavatthuppakarana, texts Pāli et traduction. Paris: Ecole francaise d'extreme-Orient. Visuddhimagga. Translation by Bhikkhu Ñannamoli, The Path of Purification. Kandy: Buddhist Publication Society, 1975, 1991. Available online: http:/ /www.tipitaka.org/romn/ (accessed on 13 March 2018).

\section{Secondary Sources}

Balbir, Nalini. 2009. Attitudes indiennes vis-a vis de l'animal domestique. In Penser, dire et représenter l'animal dans le monde indien. Edited by Nalini Balbir and Georges-Jean Pinault. Paris: Librairie Honoré Champion, pp. 811-58.

Blackburn, Anne M. 1999. Magic in the Monastery: Textual Practice and Monastic Identity in Sri Lanka. History of Religions 38: 354-72. [CrossRef]

Bollée, Willem. 2006. Gone to the Dogs in ancient India. Munchen: Verlag der Bayerischen Akademie der Wissenshaften.

Deleanu, Florin. 2000. Buddhist 'Ethology' in the Pāli Canon: Between Symbol and Observation. Eastern Buddhist XXXII: 79-127.

Doniger, Wendy. 2009. Hindus:An Alternative History. Chicago: University of Chicago Press.

Granoff, Phyllis. 2010. Karma, Curse or Divine Illusion: The Destruction of the Buddha's Clan and the Slaughter of the Yadavas. In Epic and Argument in Sanskrit Literary History: Essays in Honor of Robert P Goldman. Edited by Sheldon Pollock. Delhi: Manohar, pp. 75-91.

Granoff, Phyllis. 2017. How to make and spend money: Some stories from Indian classical literature. Paper presented at a Conference "Buddhism and Business" (UBC 2017), Vancouver, BC, Canada, June 16-18.

Masset, Daniel. 2009. Le chien a-t-il la nature du Bouddha. In Penser, dire et représenter l'animal dans le monde indien. Edited by Nalini Balbir and Georges-Jean Pinault. Paris: Librairie Honoré Champion, pp. 573-97.

Matsumura, Junko. 1992. The Rasavāhinī of Vedeha Thera Vaggas V and VI; The Migapotaka-Vagga and the Uttaroliya-Vagga. Osaka: Toho Shuppan, Inc.

Ohnuma, Reiko. 2017. Unfortunate Destiny: Animals in the Indian Buddhist Imagination. Oxford: Oxford University Press.

Rahula, Telwatte. 1984. The Rasavāhinī and the Sahassavatthu: A Comparison. Journal of the International Association of Buddhist Studies 7: 169-85.

Schmithausen, Lambert, and Mudagamuwe Maithrimurthi. 2009. Attitudes Towards Animals in Indian Buddhism. In Penser, dire et représenter l'animal dans le monde indien. Edited by Nalini Balbir and Georges-Jean Pinualt. Paris: Librairie Honoré Champion, pp. 47-121.

White, David Gordon. 1991. Myths of the Dog Man. Chicago: University of Chicago Press.

Wood, Martin. 2015. Jalarām Bāpā: Miracles and Meaning in Nineteenth Century Gujarāt. In Religious Transformation in Modern Asia. Edited by David Kim. Leiden: E.J. Brill, pp. 113-38.

Zwalf, Wladimir. 1996. A Catalogue of the Gandhāra Sculpture in the British Museum. London: British Museum Press, vol. 2. 
(C) 2019 by the author. Licensee MDPI, Basel, Switzerland. This article is an open access article distributed under the terms and conditions of the Creative Commons Attribution (CC BY) license (http:/ / creativecommons.org/licenses/by/4.0/). 